\title{
Perancangan Sistem Informasi Pelayanan Travel Haji Dan Umroh
}

\author{
$\underline{\text { Yulia Arvita }}$ \\ Teknik Informatika, Fakultas Ilmu Komputer, Universitas Dinamika Bangsa \\ Jl. Jendral Sudirman, Thehok - Jambi, Indonesia \\ yulia_arvita@yahoo.co.id
}

\begin{abstract}
The Hajj and Umrah travel activities still use conventional systems which have many shortcomings amid the demands of the use of information technology. This resulted in business activities on this travel that could not be carried out optimally in managing and accessing information and pulling data on prospective pilgrims for Haj and Umrah. To provide the best service to prospective pilgrims, an information system for Hajj and Umrah services was designed. This research produced a prototype of the Hajj and Umrah service information system with the feature of prospective pilgrims being able to view information about Haj and Umrah packages, schedule of rituals and being able to register for Haj and Umrah through the system while for employees it facilitates administrative management of prospective pilgrims for Haj and Umrah and can also help. make reports quickly, briefly, accurate and precisely in order to provide the best service to prospective Haj and Umrah pilgrims.
\end{abstract}

Keywords : prototype, information system, hajj and umrah travel, hajj and umrah service information system

\begin{abstract}
Abstrak
Selama ini pada travel haji dan umroh kegiatan bisnisnya masih menggunakan sistem konvensional yang banyak kekurangannya ditengah tuntutan penggunaan teknologi informasi. Hal ini mengakibatkan kegiatan bisnis pada travel ini tidak bisa dijalankan secara optimal dalam mengelola dan mengakses informasi dan menarik data calon jamaah haji dan umroh. Untuk memberikan pelayanan terbaik kepada calon jamaah maka dirancanglah sebuah sistem informasi pelayanan haji dan umroh. Penelitian ini menghasilkan sebuah prototype sistem informasi pelayanan haji dan umroh dengan fitur calon jamaah dapat melihat informasi mengenai paket haji dan umroh, jadwal manasik dan bisa mendaftar haji dan umroh melalui sistem tersebut sedangkan untuk karyawan memudahkan pengelolaan administratif calon jamaah haji dan umroh dan juga dapat membantu membuat laporan secara cepat singkat akurat dan tepat guna memberikan pelayanan terbaik kepada calon jamaah haji dan umroh.
\end{abstract}

Kata kunci : prototype, sistem informasi, travel haji dan umroh, sistem informasi pelayanan haji dan umroh

\section{Pendahuluan}

Pada perkembangan teknologi dan informasi saat ini, sudah banyak perusahaan yang beralih dari sistem yang konvensional ke sistem informasi yang bisa mendukung perusahaan melakukan berbagai kegiatan. Seiring perkembangan komunikasi yang sangat pesat, sampai saat ini intranet telah banyak di bahas bahkan digunakan oleh berbagai perusahaan organisasi, bahkan perorangan, sehingga membangkitkan minat bagi perusahaan [1]. Sistem informasi merupakan suatu komponen yang terdiri dari manusia, teknologi informasi, dan prosedur kerja yang memproses, menyimpan, menganalisis, dan menyebarkan informasi untuk mencapai suatu tujuan [2].

Haji merupakan rukun islam yang ke lima yang wajib dilaksanakan bagi yang mampu. Namun dengan lamanya pemberangkatan haji zaman sekarang masyarakat lebih banyak yang melaksanakan umroh, karena umroh lebih cepat dilaksanakan dan waktunya lebih singkat [3]. Selama ini pada travel haji dan umroh masih menggunakan sistem konvensional yang masih banyak kekurangannya ketika digunakan di zaman yang pada umumnya sudah menggunakan sistem informasi. Sistem informasi dalam suatu perusahaan dirasakan sangatlah penting untuk menunjang tercapainya tujuan perusahaan. Dalam hal ini adalah sistem informasi peserta haji dan umroh, karena tanpa adanya sistem yang baik tentu akan berakibat fatal bagi keuangan perusahaan [4]. Dengan dukungan teknologi informasi saat ini dapat membuat perusahaan memiliki keunggulan kompetitif, artinya perusahaan bisa bersaing dengan perusahaan lain dengan menggunakan sistem informasi.

Keberadaan sistem informasi ini tidak hanya bermanfaat bagi perusahaaan tetapi juga bagi konsumen, sehingga memudahkan konsumen untuk mendapatkan informasi apa yang mereka butuhkan. Kemajuan 
ilmu pengetahuan dan teknologi membimbing kepada bagaimana memudahkan dan mengoptimalkan pelayanan haji dan umroh [5]. Keberadaan sistem informasi yang tepat perlu diterapkan untuk pengolahan data dan melakukan pelayanan kepada calon jemaah [6].

Dalam melakukan pelayanan kepada calon jamaah haji dan umroh, perusahaan masih meggunakan cara yang konvensional artinya karyawan menginput data pada formulir pendaftaran kemudian memindai dan mengarsipkan berkas pelengkap, ketika waktu keberangkatan tiba seringnya berkas tersebut tercecer bahkan ada dokumen yang hilang akibat dari banyaknya dokumen yang akan dipersiapkan. Selain itu juga untuk membuat laporan manifestnya juga di lakukan secara konvensional, data calon jamaah haji di input satu persatu ke dalam Microsoft Excel berdasarkan berkas ataupun formulir pendaftaran yang di kumpulkan ke karyawan, sehingga memakan waktu yang lama dalam melakukan proses pendaftaran, pembayaran dan persiapan laporan calon jamah [7].

Solusi permasalahan di atas adalah merancan Sistem Informasi Pelayanan Travel Haji dan Umroh. Melalui sistem informasi ini calon jamaah dapat melihat informasi mengenai paket haji dan umroh, jadwal manasik dan bisa mendaftarkan haji dan umroh melalui sistem tersebut. Sistem ini membantu karyawan dalam proses pendataan, meminimalisir kehilangan dan penumpukan dokumen calon jamaah haji dan umroh dan juga membantu mempersiapkan laporan secara cepat dan tepat.

\section{Metodologi}

Metodologi yang digunakan dalam penelitian ini berguna sebagai pedoman untuk menyelesaikan tahapan penelitian dan sebagai acuan yang sistematis.

1. Identifikasi masalah

Pada tahapan ini peneliti mengidentifikasi masalah yang ada pada travel dan menjelaskan apa yang telah di analisa di sana sehingga tahapan identifikasi masalah ini nanti dapat di ukur sebagai langkah awal dari tahapan penelitian

2. Studi literatur

Pada tahapan ini peneliti memahami, mempelajari, menganalisa, dan mengolah bahan penelitan, teori - teori, pedoman - pedoman, referensi yang akan di gunakan dalam menyelesaikan masalah sehingga di harapakan nanti dapat memperoleh informasi yang di dapat dari studi literatur ini sehingga dapat menjadi rujukan untuk memperkuat dokumen - dokumen yang ada.

3. Pengumpulan data

a. Wawancara

Pada tahap ini peneliti melakukan wawancara dalam mengindentifikasi sistem yang sedang berjalan sehingga mendapatkan informasi yang akurat dari sumber yang terpercaya yang dapat di jadikan data dalam pembuatan penelitian ini

b. Observasi

Pada tahap ini peneliti mengamati proses dan mekanisme kerja pada travel sehingga mendapatkan informasi pengetahuan yang berguna untuk melanjutkan penelitian ini

4. Analisa kebutuhan sistem

Pada tahap kebutuhan sistem ini di lakukan analisa yang lebih mendalam terhadap sistem yang sedang berjalan sehingga bisa memahami apa yang di butuhkan untuk membangun sistem yang baru dan mengetahi kelemahan dari sistem yang sedang berjalan sehingga memperoleh sebuah sistem yang baru hasil perbaikan dari sistem yang sedang berjalan tersebut.

5. Desain pemodelan sistem

Tujuan dari tahapan ini adalah untuk memberikan gambaran secara umum tentang sistem yang baru dan mengidentifikasi komponen - komponen sistem informasi yang akan di desain. Pada tahapan ini akan di gunakan diagram UML

6. Desain prototype

Berdasarkan hasil desain pemodelan sistem tadi selanjutnya peneliti akan menggunakan metode prototype dimana pada metode ini akan dilakukan pengembangan sistem yang menggunakan pendekatan untuk membuat program secara cepat serta bertahap sehingga bisa langsung di lakukan evaluasi untuk melihat feedback yang di hasilkan dari desain ini. 


\section{Hasil dan Pembahasan}

\subsection{Analisis Sistem yang sedang berjalan}

Proses pelayanan haji dan umroh pada travel diawali dengan pengisian formulir kepesertaan disertai dengan informasi jadwal keberangkatan dan apa saja yang harus dipersiapkan. Secara rinci alur pelayanan Haji dan Umroh terlihat sebagai berikut :

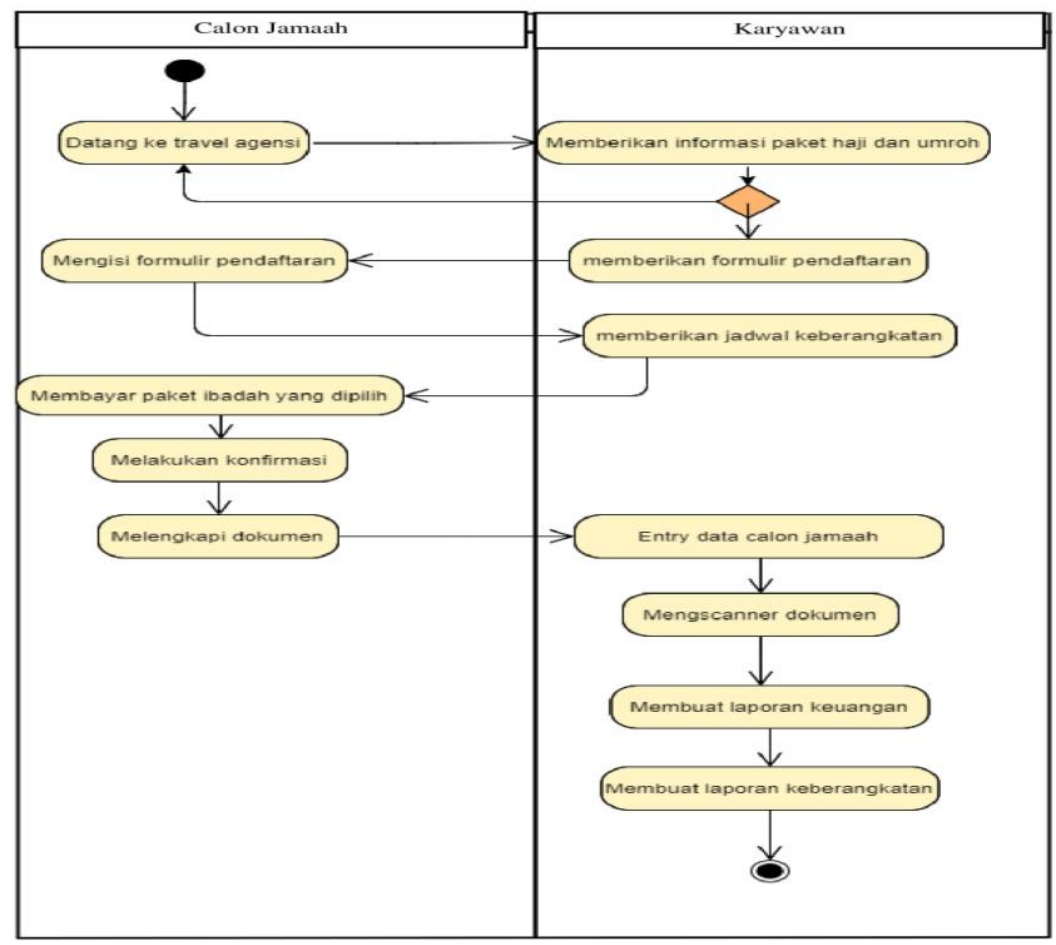

Gambar 1. Activity Diagram Sistem yang sedang berjalan

Dari permasalahan yang ada maka dibuatkanlah sebuah sistem baru, usulan perbaikan dari sistem yang lama. Sistem informasi ini akan memudahkan karyawan dalam melakukan pendaftaran dan meminimalisir terjadi nya kehilangan dokumen akibat banyak nya dokumen yang harus di siapkan dalam keberangkatan haji dan umroh ini. Selain itu dengan adanya sistem ini maka karyawan akan lebih mudah dalam mengelola paket haji dan umroh mengingat paket haji dan umroh ini terkadang bisa berubah mengikuti perkembangan zaman, karyawan juga bisa mengatur jadwal manasik, bisa mengelola pembayaran serta bisa lebih cepat tepat dan akurat dalam membuat laporan keberangkatan dan laporan keuangan.

\subsection{Usecase Diagram}

Use case diagram adalah diagram yang menggambarkan interaksi antara sistem dengan sistem ekternal dan pengguna [8]. Use case diagram juga menggambarkan tentang bagaimana cara kerja sistem yang akan di bangun. Usecase diagram juga menjelaskan apa yang dilakukan oleh sistem yang akan di bangun dan siapa yang berinteraksi dengan sistem. 


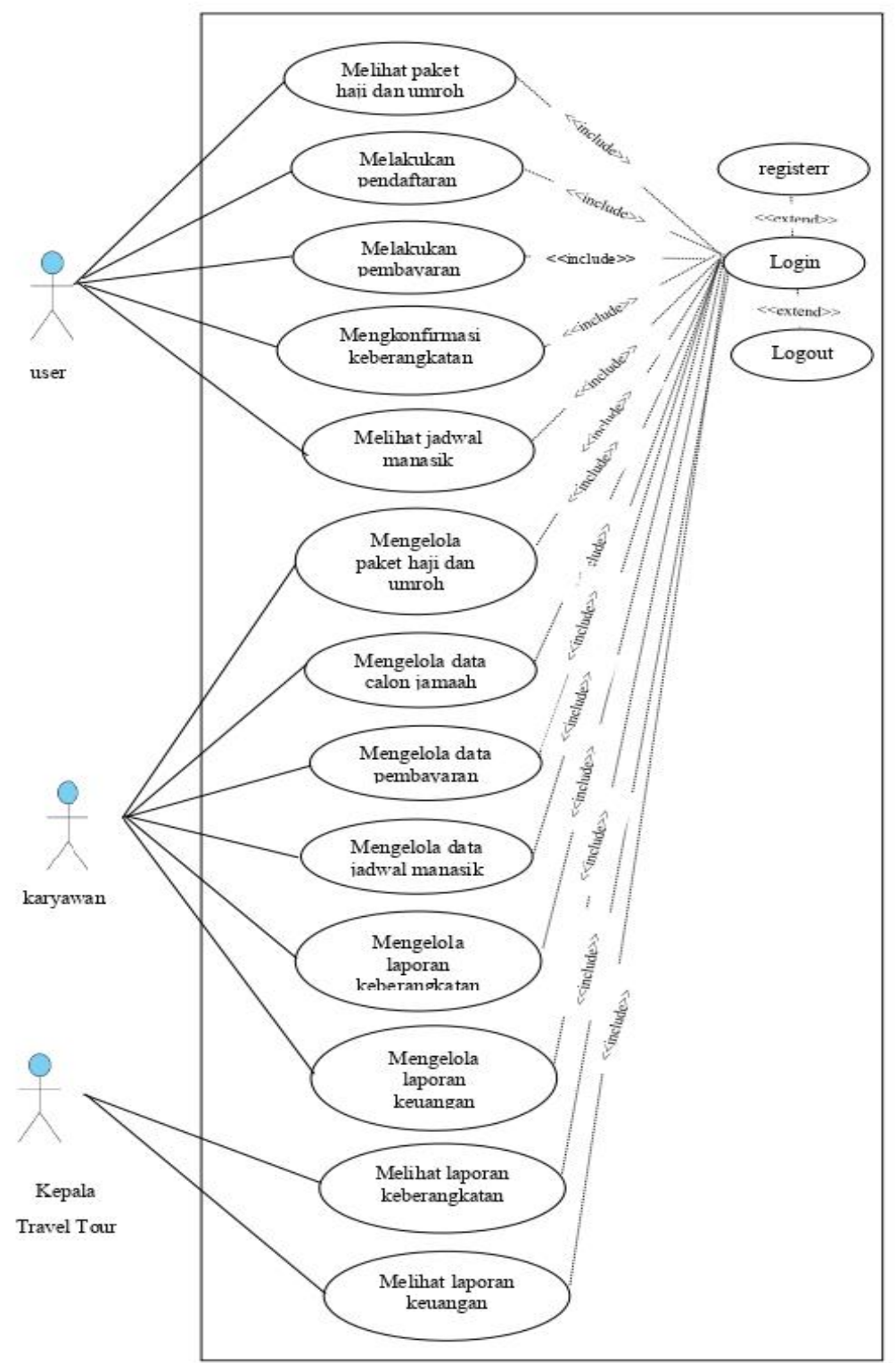

Gambar 2. Usecase Diagram Sistem Informasi Pelayanan Haji dan Umroh

\subsection{Class Diagram}

class diagram adalah diagram yang digunakan untuk menampilkan beberapa kelas serta paket - paket yang ada di dalam perangkat lunak [9]. Class diagram pada bagian ini digunakan untuk menjelaskan hubungan antar class yang ada pada sistem dan bagaimana masing - masing class saling berhubungan untuk mencapai suatu tujuan [10]. gambar di bawah ini merupakan class diagram sistem informasi pelayanan haji dan umroh. 


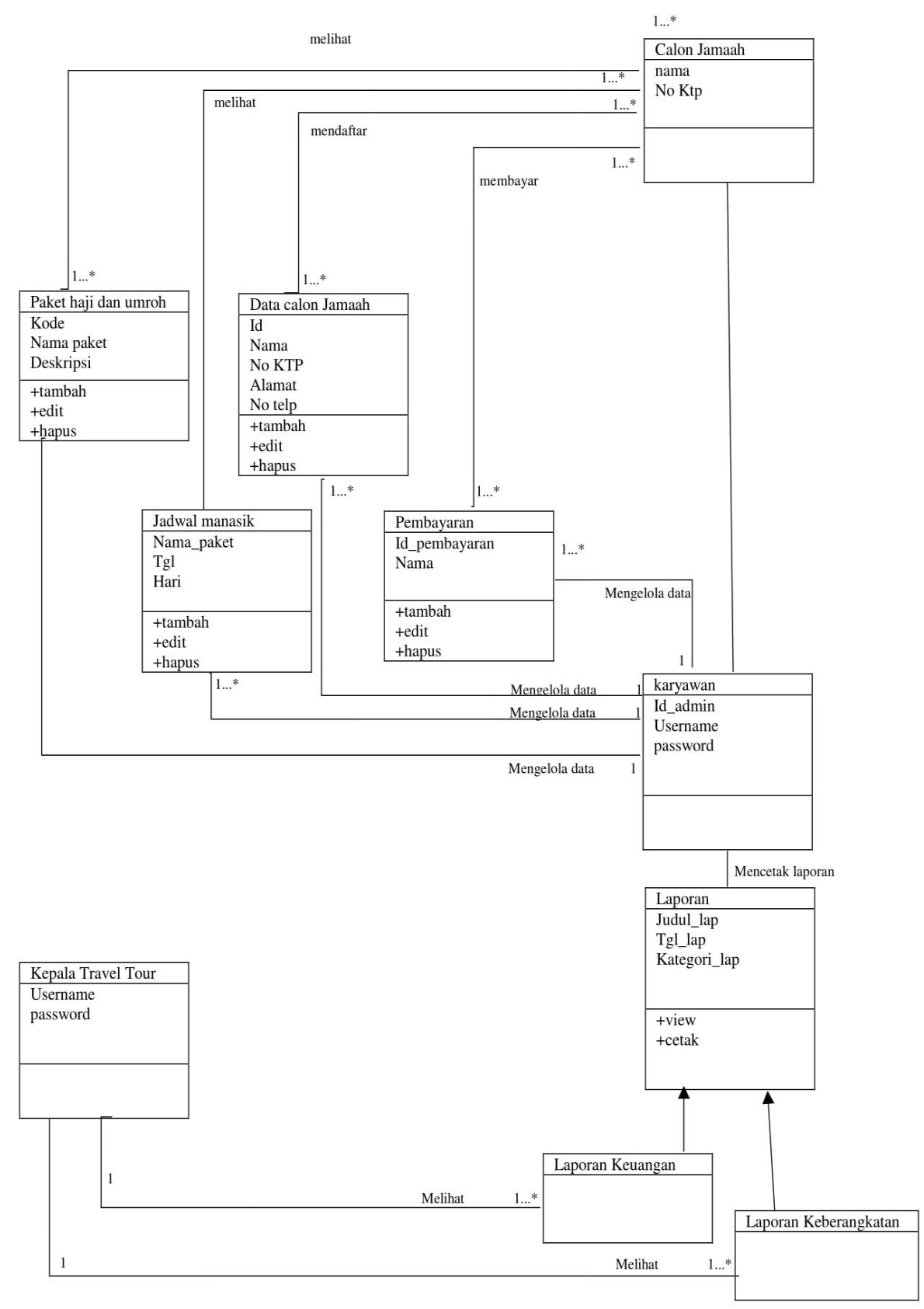

Gambar 3. Class Diagram Sistem Informasi Pelayanan Haji dan Umroh

\subsection{Hasil Implementasi}

Implementasi merupakan tahapan menerjemahakan hasil desain ke dalam suatu bentuk sistem. Sistem yang dirancang berupa sistem web, dimana sistem ini nanti akan digunakan dalam pelayanan haji dan umroh.

1. Menu Utama

Tampilan menu utama ini adalah halaman awal beranda dari Travel Tour Haji dan Umroh. Pada menu utama ini terdapat menu untuk registrasi bagi calon jamaah haji, menu login, informasi mengenai Pakt Haji dan Umroh serta galeri kegiatan. 


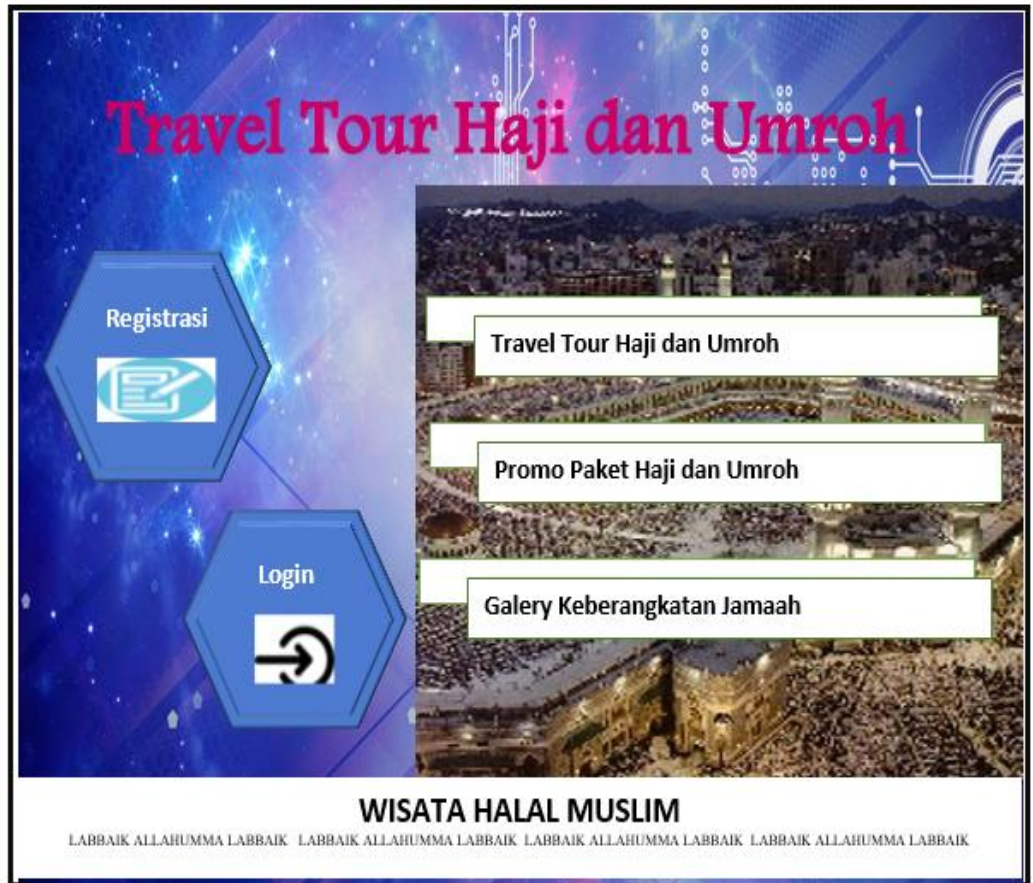

Gambar 4. Form Menu Utama

2. Form Login

Form login ini digunakan untuk masuk ke dalam menu yang tersedia. Form login ini bisa digunakan untuk calon jamaah dengan ketentuan bahawa sebelumnya sudah melakukan registrasi, dan bisa juga digunakan oleh karyawan dan kepala tour travel yang memiliki akses tersendiri.

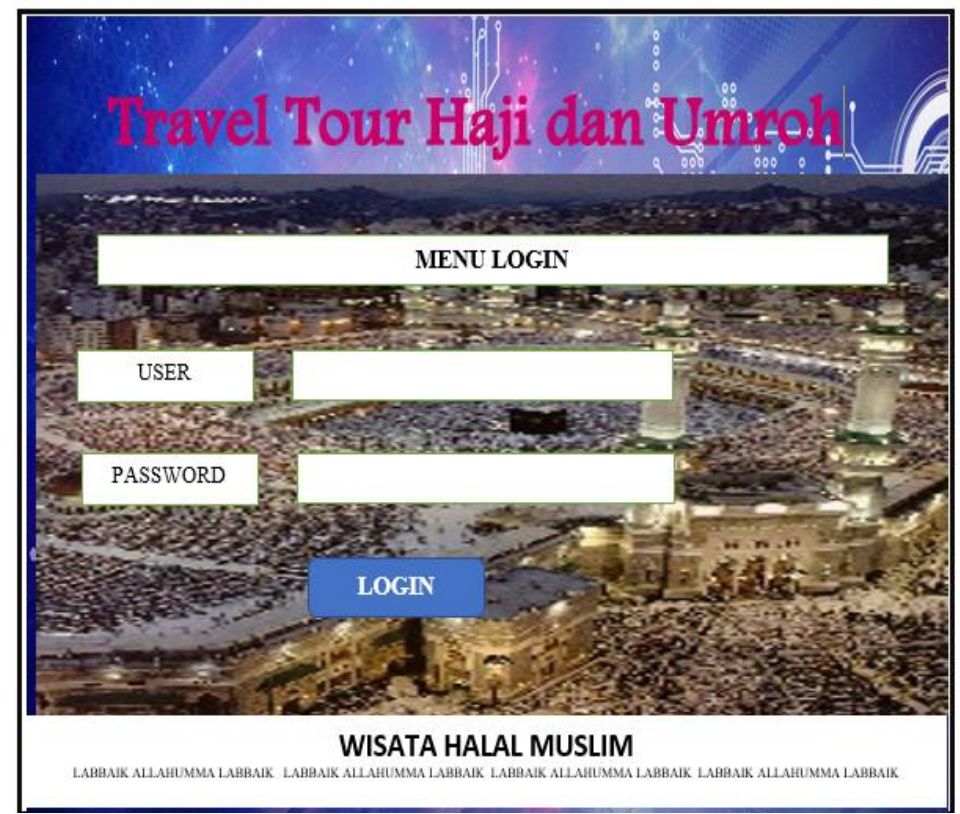

Gambar 5. Form Menu Login

3. Form Paket Haji dan Umroh

Form paket haji dan umroh ini berisi mengenai informasi paket haji dan umroh yang tersedia, ketika dipilih paket yang tertera maka akan diberikan informasi mengenai paket tersebut dilengkapi juga 
dengan informasi fasilitas apa yang didapatkan, harga yang tertera, jenis keberangkatan dan berisi informasi lainnya

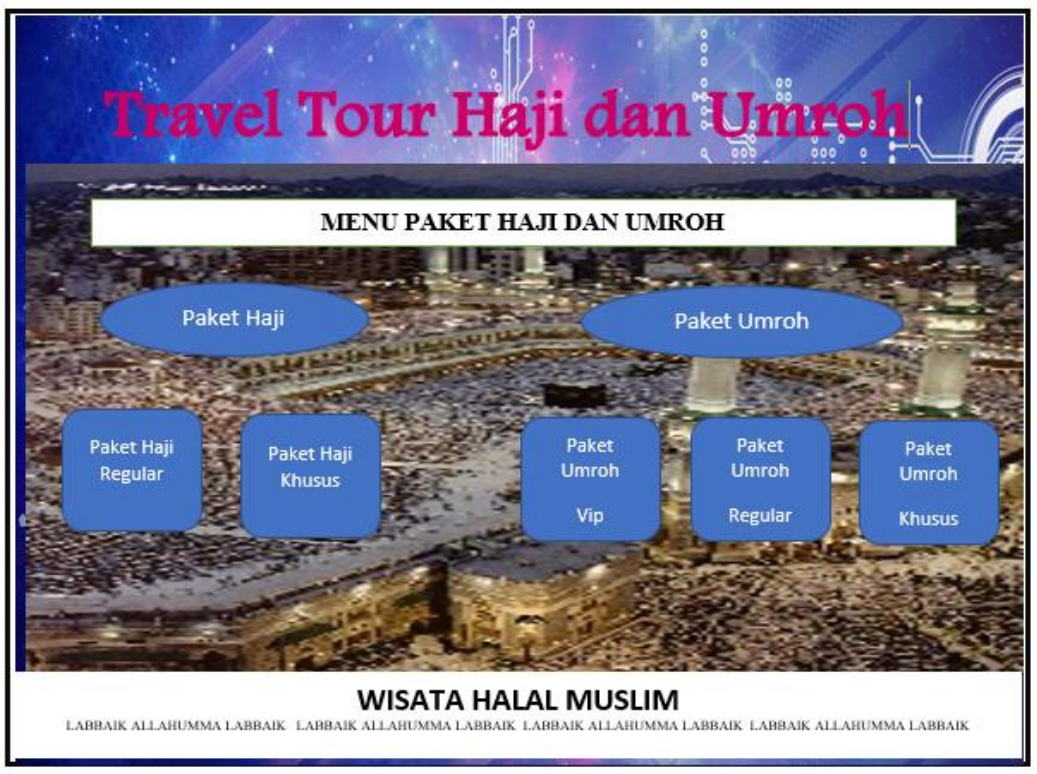

Gambar 6. Form Menu Paket Haji dan Umroh

4. Form Menu Pendaftaran

Form menu pendaftaran ini berisi form pendaftaran untuk calon jamaah haji dan umroh, pada form ini nanti bisa di pilih paket haji dan umroh apa yang dikehendaki, dan juga tertera pilihan berbagai jadwal keberangkatan dan juga total biayanya.

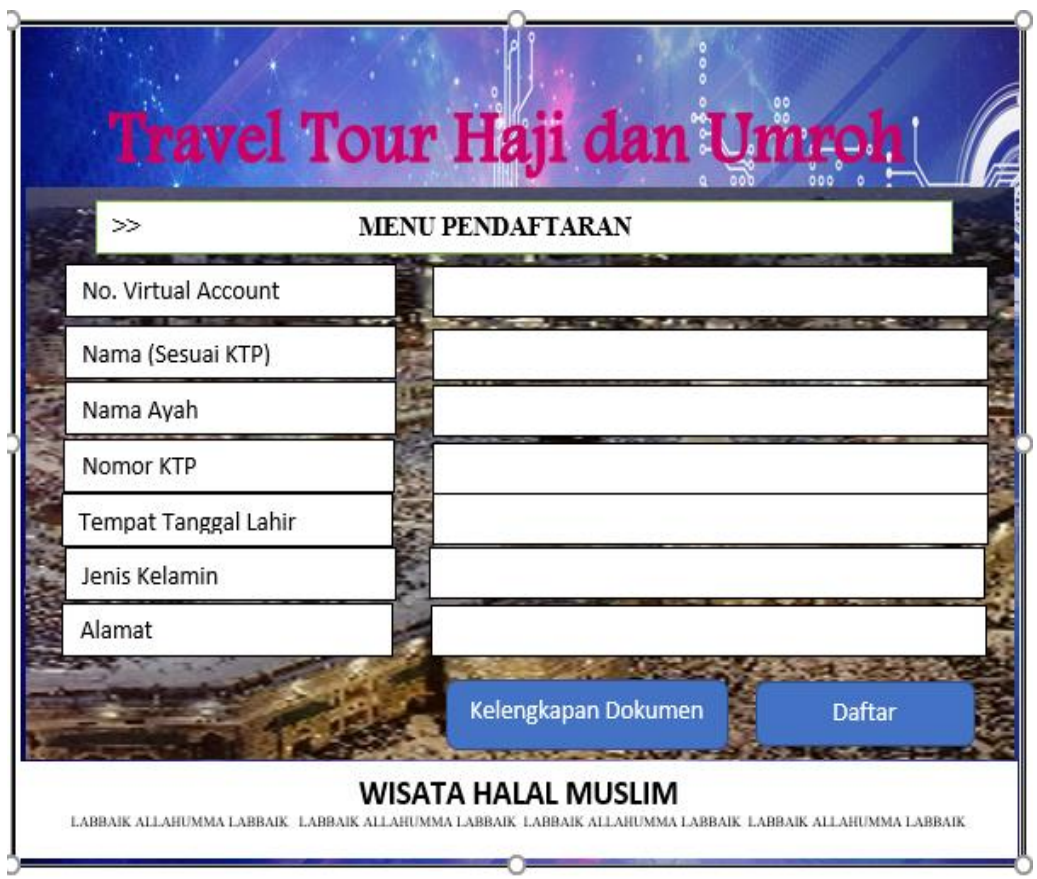

Gambar 7. Form Menu Pendaftaran Haji dan Umroh

5. Form Mengelola Data Jamaah

Form mengelola data jamaah ini digunakan oleh karyawan atau admin untuk mengelola data jamaah, mengubah dan mencetak ataupun menghapus data calon jamaah haji dan umroh. 


\section{SISTEM INFORMASI PELAYANAN HAJI DAN UMROH}

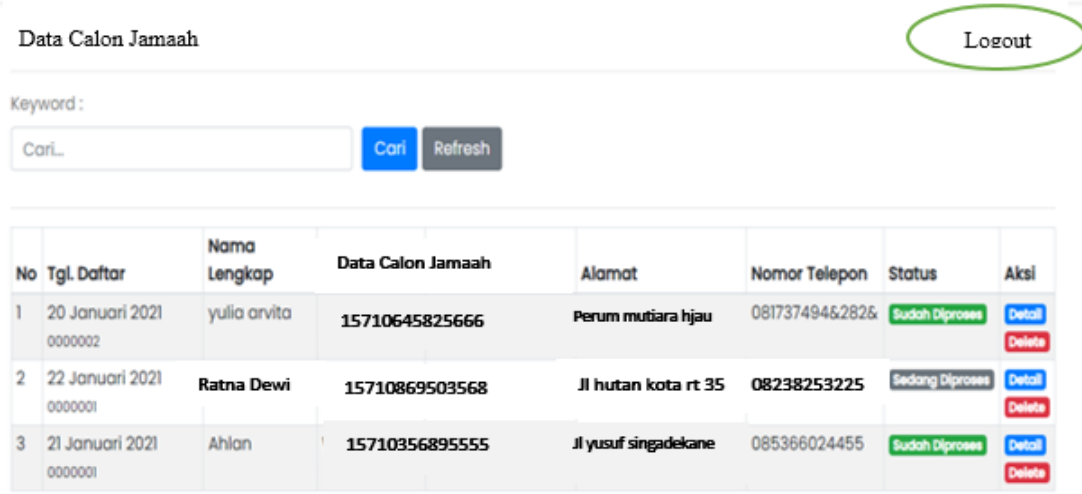

@ copyright2021 - Wisata Halal Muslim

Gambar 8. Menu Mengelola Data Jamaah

6. Form Mengelola Pembayaran

Form mengelola data pembayaran ini digunakan oleh karyawan atau admin untuk mengelola data pembayaran calon jamaah haji dan umroh. Melalui halaman ini admin mengkonfirmasi status pembayaran calon jamaah.

\section{SISTEM INFORMASI PELAYANAN HAJI DAN UMROH}

\section{Data Pembayaran Jamaah}

Keyword:

Cori. Cari Rotrosh

\begin{tabular}{|c|c|c|c|c|c|c|}
\hline No & Tgl Doftor & $\begin{array}{l}\text { Nama } \\
\text { Longkap }\end{array}$ & Jumlah Pembayaran & $\begin{array}{l}\text { Paket yang di } \\
\text { pilih }\end{array}$ & Nomer Telepon & Stotus \\
\hline 1 & $\begin{array}{l}\text { 20 Janvari } 2021 \\
\text { 00000002 }\end{array}$ & yulia anvito & Rp. 25.000 .000 ; & Umroh roguar & 18173749482826 & Sudah Diproses \\
\hline 2 & $\begin{array}{l}\text { 22 Jonuori } 2021 \\
0000004\end{array}$ & Ratna Dewi & Rp. 28.000 .000 ; & Umfoh VIP & 082382532253 & Sudah Diproses \\
\hline 3 & $\begin{array}{l}\text { 21 Januari 2021 } \\
0000003\end{array}$ & Ahian & Rp. 25.000 .000 , & Umroh roguar & 185366024455 & Sudoh Diproses \\
\hline
\end{tabular}

Gambar 9. Menu Mengelola Data Pembayaran

\subsection{Hasil Pengujian}

Pengujian sistem dilakukan dengan teknik black box testing agar sistem dapat berfungsi sesuai dengan tampilan dan algoritma sistem yang ditetapkan. Tabel 1 memaparkan hasil pengujian yang telah dilakukan.

Tabel 1 Pengujian Sistem

\begin{tabular}{llllll}
\hline No & \multicolumn{1}{c}{ Deskripsi } & Masukan & \multicolumn{1}{c}{$\begin{array}{c}\text { Keluaran yang di } \\
\text { harapkan }\end{array}$} & $\begin{array}{c}\text { Hasil } \\
\text { Pengujian }\end{array}$ & Kesimpulan \\
\hline 1 & $\begin{array}{l}\text { Pengujian pada } \\
\text { registrasi user } \\
\text { baru }\end{array}$ & $\begin{array}{l}\text { Klik tombol } \\
\text { registrasi }\end{array}$ & $\begin{array}{l}\text { User baru tersimpan di } \\
\text { dalam database dan bisa } \\
\text { digunakan untuk login ke } \\
\text { sistem }\end{array}$ & sesuai & Valid \\
& & $\begin{array}{l} \\
\text { sidem }\end{array}$ & \\
\end{tabular}


2 Pengujian pada menu paket haji dan umroh

\section{Pengujian pada} menu pendaftaran
Klik tombol yang ingin dilihat

Klik tombol
pendaftaran

4 Pengujian pada menu mengelola data jamaah

\begin{abstract}
Klik tombol detail pada data yang di pilih
\end{abstract}

Klik tombol delete pada data yang di pilih

\section{Sistem menampilkan informasi sesuai dengan yang dipilih oleh user}

Sistem menampilkan form pendaftaran, dan menyimpan hasil pendaftaran ke dalam database.

Sistem menampilkan form data calon jamaah dan tombol edit dan cetak

- Klik edit maka sistem akan menampilkan form data calon jamaah untuk di edit

- Klik cetak maka Sistem menampilkan form data jamaah untuk di cetak

Sistem menampilkan notifikasi untuk menghapus data calon jamaah

- klik ya maka sistem akan menghapus data calon jamaah

- klik tidak maka sistem akan kembali ke menu mengelola data jamaah

Klik data yang di pilih
Sistem menampilkan menu status yang berisi proses sudah selesai artinya calon jamaah sudah melakukan pembayaran sesuai dengan paket yang di pilih

\section{Kesimpulan}

Sistem informasi pelayanan haji dan umroh ini menyediakan informasi paket haji dan umroh beserta promo apa yang tersedia dan dapat di akses oleh masyarakat luas, menghasilkan laporan yang dapat disajikan secara cepat dan akurat, serta meminimalisir permasalahan kehilangan dokumen calon jamaah haji dan umroh. Sistem ini dapat meningkatkan keungulan kompetitif pada perusahaan melalui layanan berbasis komputer yang semakin baik.

\section{Daftar Pustaka}

[1] Hidayah, N. A., Utami, M. C., \& Suhendar, A. T. (2015). Rancang Bangun Sistem Informasi Pelayanan Haji dan Umroh Berbasis Web (Studi Kasus: KBIH Al- Karimiyah Depok). Jurnal Sistem Informasi, 8(2), 1-12.

[2] Syarif, A., \& Kusumawati, K. (2019). Sistem Informasi Pelayanan Haji Dan Umroh Berbasis Android. Jurnal Satya Informatika, 4(2), 33-41. 
[3] Rahmatillah, I. R., \& Hikmah, A. B. (2018). Perancangan Sistem Informasi Pelayanan Administrasi Data Umroh. IJCT (Indonesian Journal on Computer and Information Technology), 3(1), 9

[4] Ardiyanto, M. (2020). Perancangan Sistem Informasi Haji Dan Umroh Pada Otto Pariwisata Ardana Tour. Semnas Ristek, 70-76.

[5] Lubis, M. S., \& Hidayat, T. (2019). Sistem Informasi Terpadu Haji Dan Umroh Berbasis Mobile. JSiI (Jurnal Sistem Informasi), 6(1), 62. https://doi.org/10.30656/jsii.v6i1.1064

[6] R.Rahmatillah \& Agung. B, "Perancangan Sistem Informasi Pelayanan Administrasi Umroh (Studi Kasus PT Utsmaniyyah Hannien Tour Tasikmalayan," 9 -17

[7] A. Aris, "Sistem Informasi Pelayanan Umroh Alkhairat Group Berbasis Web," J. Ilm. Inform., vol. 3, no. 1, pp. 213-219, 2020, doi: 10.35316/jimi.v3i1.629

[8] A. Hidayatullah, S. J. Putra, and I. Qoyim, "Rancang Bangun Sistem Informasi Pemesanan Program Umroh pada PT Arqom Bayu Nusaba,” J. Sist. Inf., vol. 7, no. 2, pp. 1-8, 2014.

[9] W. S. Prasetya, "Penerapan Extreme Programming," Sensitif, pp. 1313-1322, 2019.

[10] Hidayat, A. S., \& Kurniawan, T. A. (2019). Rancang Bangun Sistem Informasi Pelayanan Haji Dan Umroh Pada Pt. Arminareka Perdana. 205-215. 